\title{
Fatty acids and flavours in milk from dairy cows fed no synthetic vitamins ${ }^{*}$
}

\author{
H. Danielsson ${ }^{1,4}$, B. Johansson ${ }^{1}$, E. Nadeau ${ }^{1}$, K. Persson Waller ${ }^{2}$ \\ and S.K. Jensen ${ }^{3}$ \\ ${ }^{1}$ Department of Animal Environment and Health, Swedish University of Agricultural Sciences \\ P.O. Box 234, SE-532 23 Skara, Sweden \\ ${ }^{2}$ Department of Pigs, Poultry and Ruminants, National Veterinary Institute (SVA) \\ SE-751 89 Uppsala, Sweden \\ ${ }^{3}$ Department of Animal Health, Welfare and Nutrition, Danish Institute of Agricultural Sciences, \\ Research Centre Foulum \\ P.O. Box 50, DK-8830 Tjele, Denmark
}

\begin{abstract}
The aim of this study was to investigate the effects of feeding no synthetic vitamins to dairy cows, fed a $100 \%$ organic diet, on the organoleptic quality and fatty acid composition of the milk. A 12-month study was performed at Tingvall Organic Dairy Research Farm. Individual milk samples for organoleptic analysis were collected at six occasions from 50 cows, equally allocated into two treatments, one with vitamin supplementation and one without. Monthly composited milk samples from each treatment were collected for analysis of organoleptic quality and fatty acid composition. The results indicate that supplementation of synthetic vitamins according to Swedish recommendations do not generally affect organoleptic quality and fatty acid composition of the milk.
\end{abstract}

KEY WORDS: off-flavour, antioxidant, fatty acid, milk quality

\section{INTRODUCTION}

Oxidation of polyunsaturated fatty acids (PUFA) causes oxidative off-flavours in milk. Both $\beta$-carotene and $\alpha$-tocopherol are important antioxidants and, consequently, limit oxidation of fatty acids (FA; Charmley and Nicholson, 1994; Jensen et al., 1999). Results by Ellis et al. (2006) have shown that organic milk has a higher content of PUFA and n-3 FA than milk from conventional herds. Both

\footnotetext{
* Supported by The Swedish Farmers' Foundation for Agricultural Research

${ }^{4}$ Corresponding author: e-mail: Hanna.Danielsson@hmh.slu.se
} 
PUFA and n-3 FA are essential FA and are reported to be beneficial to human health (Hu and Willett, 2002), but a higher content of PUFA can result in milk that is more susceptible to oxidation (Charmley and Nicholson, 1994). Supplementation of $\alpha$-tocopherol can increase the oxidative stability of milk (Focant et al., 1998).

According to EU regulations, use of synthetic vitamins in organic ruminant production was prohibited from August 2000 until December 2005. There was, however, an exemption from the prohibition in the entire EU during the same period due to limited possibilities to produce the natural vitamins A, D and E. The aim of this study was to investigate the effects of feeding no synthetic vitamins to dairy cows, fed a $100 \%$ organic diet, on the organoleptic quality and FA composition of the milk.

\section{MATERIAL AND METHODS}

\section{Design and treatments}

The experiment performed at Tingvall Organic Dairy Research Farm, The Rural Economy and Agricultural Societies (Sweden) started in November 2004 when the first cows in the trial started to calf, and continued for one year. The herd consisted of Swedish Holstein cows, which were kept in a loose housing system and were milked twice daily at 5.30 and 15.30 .

Cows and pregnant heifers were paired according to calving date, parity and milk yield of the last lactation for mulitparous cows or breeding index for heifers, and then randomly allocated to two treatments with 25 cows in each group. The vitamin treatments (with or without synthetic vitamins) were given to the cows in a $100 \%$ organic diet for one year before the milk was sampled for organoleptic quality and FA content.

\section{Samplings, recordings and analysis}

Individual milk samples were collected 4 days (early), 3-5 months (mid) and 7-9 months (late) after calving to determine organoleptic variations of the milk during lactation. Effect of season was determined by collecting individual milk samples in December, March and July. Individual milk samples were subjected to organoleptic analysis at the Gäfleorten dairy plant. Analysis of organoleptic characteristics in pooled milk samples from each group was performed at Steins Inc. All samples were stored in $6^{\circ} \mathrm{C}$ for $24 \mathrm{~h}$ before being frozen and sent for analysis. All analyses were performed within six months from sampling. Individual milk yield, fat and protein contents were registered once a month.

The fatty acid composition of pooled milk samples from each group was determined at Kungsängen Research Centre laboratory, Swedish University of Agricultural 
Sciences, Uppsala. The lipids were extracted using hexane and isopropanol (NouroozZadeh and Appelquist, 1988), followed by methylation of FA (Sukija and Palmquist, 1988) and separation with a temperature-programmed gas chromatograph (HP5890, HP88, J\&W Scientific, USA). Simultaneously, feed samples were analysed for FA composition. The FA analyses in feed were the same as for milk after methylation of the FA in the feed samples (Sukhija and Palmquist, 1988).

\section{Feeds and feeding}

Both groups were offered the same $100 \%$ organic feed fed as a semi-mixed ration with, kg dry matter (DM): silage 12.9, cold-pressed rapeseed cake 2.7, pea 3.3, barley 3.6, triticale 2.3 and minerals 0.2 during the first three months of lactation. During the remaining lactation, cows were fed, $\mathrm{kg}$ DM: silage 12.9 and cold-pressed rapeseed cake a maximum of 1.7 , pea 2.3 , barley 2.5 , triticale 1.6 and minerals 0.15. During the grazing period from May until September 2005, $8.9 \mathrm{~kg}$ DM silage was replaced by pasture and cows were indoors only during milking. The difference between the two diets was the vitamin supplementation of 8759-11594 IU, 2190-2899 IU and 450-600 IU per day of vitamins A, D and E, respectively. Cows in treatment "without" (WO) were fed minerals without synthetic vitamins and cows in treatment "with" (W) were fed minerals with synthetic vitamins.

The feeds fed to the cows contained various amounts of FA and the most abundant FA in the feed are listed in Table 1. The silages contained $60-65 \%$

Table 1 . The most abundant fatty acids ( $\mathrm{g} / 100 \mathrm{~g}$ fatty acids) in the feeds

\begin{tabular}{|c|c|c|c|c|c|c|c|c|}
\hline \multirow{3}{*}{ Fatty acid } & & \multirow{3}{*}{ Barley } & \multirow{3}{*}{ Pea } & \multirow{3}{*}{$\mathrm{RSC}^{1}$} & \multicolumn{3}{|c|}{ Silage } & \multirow{3}{*}{ Pasture } \\
\hline & & & & & \multicolumn{2}{|c|}{ harvest } & \multirow{2}{*}{$\begin{array}{l}\text { round } \\
\text { baled }\end{array}$} & \\
\hline & & & & & $1^{\text {st }}$ & $2^{\text {nd }}$ & & \\
\hline C16:0 & Palmitic & 25.0 & 13.8 & 4.9 & 15.9 & 16.6 & 17.6 & 18.2 \\
\hline C18:0 & Stearic & 1.2 & 3.4 & 1.7 & 1.5 & 1.4 & 2.0 & 1.8 \\
\hline C18:1 cis-9 & Oleic & 9.9 & 27.4 & 48.5 & 3.0 & 3.4 & 4.0 & 2.9 \\
\hline C18:2 cis- 9,12 & Linoleic & 55.8 & 45.4 & 26.0 & 18.3 & 18.6 & 18.1 & 17.9 \\
\hline C18:3 cis- $9,12.15$ & Linolenic & 6.2 & 8.5 & 11.9 & 52.9 & 50.3 & 49.8 & 50.6 \\
\hline Other saturated & & 0.4 & 0.5 & 1.0 & 0.7 & 0.7 & 6.8 & 6.7 \\
\hline Other unsaturated & & 1.5 & 0.8 & 6.0 & 3.7 & 3.7 & 1.4 & 1.6 \\
\hline Others & & 0.1 & 0.3 & 0 & 0.1 & 0.2 & 0.2 & 0.1 \\
\hline
\end{tabular}

${ }^{1} \mathrm{RSC}$ - cold-pressed rapeseed cake

grass (meadow fescue, timothy and perennial ryegrass) and 35-40\% clover (red-, white- and alsike clover). The diet for the first three months contained $1.2 \mathrm{~kg}$ crude fat (cf) and the diet for the remaining lactation contained $0.9 \mathrm{~kg}$ cf which represents 4.8 and $3.7 \%$ cf of the dietary DM, respectively. 


\section{Statistical analysis}

Data were analysed using SAS (2001). Differences in organoleptic quality between treatments for each of the three lactation stages were analysed by using the PROC FREQ. The distinction was between off-flavour or and oxidized flavour or other off-flavours. Wilcoxon rank-sum test in the PROC NPAR1WAY was also used to test for significant differences between the treatments. A model, in which cows were paired, was used to study the effect of season on differences in organoleptic quality of the milk between treatments, using the Wilcoxon Signed Rank Test in the PROC UNIVARIATE. Also, differences in organoleptic quality among the three lactation stages within each treatment were tested using the PROC UNIVARIATE. Data on fatty acid composition of the milk are shown as means and standard deviations (Std).

\section{RESULTS}

Average yields of milk, fat and protein were $34.9 \mathrm{~kg}$ (Std 5.11), $1.3 \mathrm{~kg}$ (Std 0.24 ) and $1.2 \mathrm{~kg}$ (Std 0.12) for cows in treatment WO, respectively, and $35.5 \mathrm{~kg}$ (Std 4.52), $1.4 \mathrm{~kg}$ (Std 0.22) and $1.2 \mathrm{~kg}$ (Std 0.12), respectively, for treatment W. Average body condition score was 3.1 (Std 0.20) and 3.0 (Std 0.19) for cows in treatment $\mathrm{WO}$ and $\mathrm{W}$, respectively.

The only significant difference in organoleptic quality between the two treatments was in July. Then the number (percentage) of milk samples with oxidized flavours was higher from cows in treatment WO (26\%) than from cows in treatment $\mathrm{W}(0 \% ; \mathrm{P}=0.018)$. There was a tendency towards more incidences of oxidation in milk from cows in early than in mid and late lactation for treatment $\mathrm{W}(\mathrm{P}=0.078)$. The same $\mathrm{P}$-value for treatment $\mathrm{WO}$ was 0.113 . The percentage of cows with oxidized flavours as a mean of the two groups was 39.1 in early and 5.4 in mid to late lactation. Number of milk samples with off-flavours tended to be higher for cows in early than in mid and late lactation for treatment WO $(\mathrm{P}=0.055)$. The percentage of cows with off-flavours averaged over the two groups was 17.2 in early and 4.0 in mid to late lactation. There were no observations on off-flavours of the pooled milk samples from each group.

There were no differences in milk FA composition between the two treatments (Table 2). However, the content of unsaturated FA in milk increased whereas the content of saturated FA in milk decreased during the grazing period (data not shown). 
Table 2. Composition of fatty acids ( $\mathrm{g} / 100 \mathrm{~g}$ fatty acids) in milk from cows fed synthetic vitamins (W) or not (WO) averaged over a 12-month period (from November 2004 until October 2005). Number of cows per group varied from 2 to 25 among the sampling dates each month

\begin{tabular}{|c|c|c|c|c|c|}
\hline \multirow{3}{*}{ Fatty acid } & & \multicolumn{4}{|c|}{ Treatment } \\
\hline & & \multicolumn{2}{|c|}{$\mathrm{W}$} & \multicolumn{2}{|c|}{ WO } \\
\hline & & mean & Std & mean & Std \\
\hline $\mathrm{C} 4: 0$ & Butyric & 3.4 & 0.3 & 3.8 & 0.3 \\
\hline C6:0 & Caproic & 2.5 & 0.3 & 2.5 & 0.3 \\
\hline $\mathrm{C} 8: 0$ & Caprylic & 1.5 & 0.2 & 1.5 & 0.2 \\
\hline C10:0 & Capric & 3.3 & 0.5 & 3.3 & 0.4 \\
\hline C12:0 & Lauric & 3.6 & 0.5 & 3.7 & 0.4 \\
\hline C14:0 & Myristic & 11.0 & 0.9 & 11.3 & 0.9 \\
\hline C16:0 & Palmitic & 24.1 & 2.3 & 26.1 & 3.1 \\
\hline C18:0 & Stearic & 12.5 & 1.1 & 11.6 & 1.0 \\
\hline C18:1 & Transvaccenic & 1.6 & 0.5 & 1.6 & 0.5 \\
\hline C18:1 & Oleic & 21.5 & 2.8 & 20.1 & 3.0 \\
\hline C18:1 & Vaccenic & 0.7 & 0.2 & 0.6 & 0.2 \\
\hline C18:2 & Linoleic & 1.7 & 0.3 & 1.7 & 0.2 \\
\hline C18:3 & Linolenic & 0.8 & 0.1 & 0.9 & 0.1 \\
\hline $\mathrm{C} 18: 2+\mathrm{C} 20: 1$ & CLA $^{1}+$ Eicosenoic & 0.7 & 0.3 & 0.7 & 0.2 \\
\hline Other saturated & & 3.5 & 0.1 & 3.5 & 0.2 \\
\hline Other unsaturated & & 6.5 & 0.9 & 6.2 & 0.9 \\
\hline Other & & 0.8 & 0.1 & 0.8 & 0.1 \\
\hline $\mathrm{SFA}^{2}$ & & 65.4 & 5.1 & 67.2 & 5.3 \\
\hline MUFA $^{3}$ & & 30.0 & 4.4 & 28.3 & 4.7 \\
\hline PUFA $^{4}$ & & 2.9 & 0.4 & 2.8 & 0.3 \\
\hline Total n-3 & & 1.0 & 0.1 & 1.0 & 0.1 \\
\hline Total n-6 & & 1.8 & 0.3 & 1.8 & 0.3 \\
\hline
\end{tabular}

${ }^{1}$ CLA - conjugated linoleic acid; ${ }^{2}$ SFA - saturated fatty acid

${ }^{3}$ MUFA - monounsaturated fatty acid; ${ }^{4}$ PUFA - polyunsaturated fatty acid

\section{DISCUSSION}

The vitamin supplementation did not result in any differences in oxidation between the milk from cows in treatments $\mathrm{W}$ and WO, except from the samples in July. This might depend on the higher content of unsaturated FA in the milk during the summer. Focant et al. (1998) has shown reduced incidence of oxidation in milk from cows supplemented with 9616 IU vitamin E per day. The vitamin E supplementation (450-600 IU/day) used in the present study was much lower, comparatively, as we wanted to compare oxidative stability in milk between cows fed no synthetic vitamins and cows fed synthetic vitamins according to Swedish recommendations (Spörndly, 2003). The results indicate that the Swedish supplementation of vitamins 
has most impact on organoleptic quality of the milk in the summer. In agreement with Focant et al. (1998), no differences in FA composition of the milk between the two treatments were found. The study also confirms former results that milk from cows in early lactation are more sensitive to oxidation than cows in mid and late lactation (Walstra and Jenness, 1984). However, this effect is diluted in the group milk samples from the farm and usually will not affect the bulk milk.

\section{CONCLUSIONS}

Cows without vitamin supplementation do not generally have a decreased oxidation stability of the milk compared to cows supplemented with vitamins according to Swedish recommendations.

\section{ACKNOWLEDGEMENTS}

The authors express their appreciation to Dr. Jan-Eric Englund for statistical advice, to herd manager Erik Hedlund and to Lars Johansson for technical assistance.

\section{REFERENCES}

Charmley E., Nicholson J.W.G., 1994. Influence of dietary fat source on oxidative stability and fatty acid composition of milk from cows receiving a low or high level of dietary vitamin E. Can. J. Anim. Sci. 74, 657-664

Ellis K.A., Innocent G., Grove-White D., Cripps P., McLean W.G., Howard C.V., Mihm M., 2006. Comparing the fatty acid composition of organic and conventional milk. J. Dairy Sci. 89, 1938-1950

Focant M., Mignolet E., Marique M., Clabots F., Breyne T., Dalemans D., Larondelle Y., 1998. The effect of vitamin E supplementation of cow diets containing rapeseed and linseed on the prevention of milk fat oxidation. J. Dairy Sci. 81, 1095-1101

Hu F.B., Willett W.C., 2002. Optimal diets for prevention of coronary heart disease. J. Amer. Med. Assn. 288, 2569-2578

Jensen S.K., Bjørnbak Johannesen A.K., Hermansen J.E., 1999. Quantitative secretion and maximal secretion capacity of retinol, $\beta$-carotene and $\beta$-tocopherol into cows' milk. J. Dairy Res. 66, 511-522

Nourooz-Zadeh J., Appelqvist L.- $\AA$., 1988. Cholesterol oxides in Swedish foods and food ingredients: Milk powder products. J. Food Sci. 53, 74-79, 87

SAS, 2001. User's Guide: Statistics. SAS, Version 8 Edition. SAS Inst., Inc., Cary, NC

Spörndly R., 2003. Feed Tables for Ruminants (in Swedish). Department of Animal Nutrition and Management, Swedish University of Agriculture Sciences. Uppsala (Sweden). Report 257

Sukhija P.S., Palmquist D.L., 1988. Rapid method for determination of total fatty acid content and composition of feedstuffs and feces. J. Agr. Food. Chem. 36, 1202-1206

Walstra P., Jenness R., 1984. Dairy Chemistry and Physics. John Wiley \& Sons, New York 